\title{
Luteolin induces apoptotic cell death via antioxidant activity in human colon cancer cells
}

\author{
KYOUNG AH KANG ${ }^{1}$, MEI JING PIAO ${ }^{1}$, YEA SEONG RYU ${ }^{1}$, YU JAE HYUN ${ }^{1}$, \\ JEONG EON PARK $^{1}$, KRISTINA SHILNIKOVA ${ }^{1}$, AO XUAN ZHEN ${ }^{1}$, HEE KYOUNG KANG ${ }^{1}$, \\ YOUNG SANG KOH ${ }^{1}$, YONG JOO JEONG ${ }^{2}$ and JIN WON HYUN ${ }^{1}$
}

${ }^{1}$ Department of Biochemistry, School of Medicine and Jeju Research Center for Natural Medicine, Jeju National University, Jeju 63243; ${ }^{2}$ Department of Bio and Nanochemistry, Kookmin University, Seoul 02707, Republic of Korea

Received April 13, 2017; Accepted June 30, 2017

DOI: 10.3892/ijo.2017.4091

\begin{abstract}
The present study determined whether luteolin induces HT-29 colon cancer cell death through an antioxidant effect such as the activation of antioxidant enzymes. Luteolin decreased cell viability in human colon cancer cells (HT-29), whereas it had no effect on normal colon cells (FHC). Luteolin induced apoptosis by activating the mitochondria-mediated caspase pathway in HT-29 cells. Luteolin caused loss of the mitochondrial membrane action potential, increased mitochondrial $\mathrm{Ca}^{2+}$ level, upregulated Bax, downregulated Bcl-2, induced the release of cytochrome $c$ from mitochondria to the cytosol, and increased the levels of the active forms of caspase-9 and caspase-3. Luteolin-induced apoptosis was accompanied by the activation of intracellular and mitochondrial reactive oxygen species scavenging through the activation of antioxidant enzymes, such as superoxide dismutase and catalase in HT-29 cells. Luteolin increased the level of reduced glutathione (GSH) and the expression of GSH synthetase, which catalyzes the second step of GSH biosynthesis. The apoptotic effect of luteolin was mediated by the activation of the mitogen-activated protein kinase signaling pathway. The present results indicate that luteolin induces apoptosis by promoting antioxidant activity and activating MAPK signaling in human colon cancer cells.
\end{abstract}

\section{Introduction}

Approximately 1.4 million new cases of colon cancer are diagnosed each year worldwide. Colon cancer is the third most common cancer in Korea, and its incidence is increasing in Asian countries, including Korea (1,2). Intensive efforts have been made to identify a causative factor for this major cancer, and epidemiologic studies indicate that a western style diet is associated with a high incidence of colon cancer (3-5).

Correspondence to: Professor Jin Won Hyun, Department of Biochemistry, School of Medicine, Jeju National University, Jeju 63243, Republic of Korea

E-mail: jinwonh@jejunu.ac.kr

Key words: luteolin, colon cancer, antioxidant, apoptosis
Reactive oxygen species (ROS) modulate growth signals and activate gene expression, leading to sustained proliferation of cancer cells (6-8). In cancer cells, ROS-induced phosphorylation of c-Jun N-terminal kinase (JNK) translates oncogenic signals, supporting cellular proliferation through the activation of activating protein-1, in addition to the proliferation signals mediated by extracellular regulated kinase (ERK) (9). Therefore, ROS likely play an important role in promoting tumor development.

Flavonoids are biologically active polyphenolic compounds widely distributed in plants, and luteolin, 3',4',5,7-tetrahydroxyflavone, is rich in vegetables and flowers. Flavonoids including luteolin have been focused on anticancer properties via various anticancer mechanisms (10-13). Luteolin have antiinflammatory, antiallergic, anticancer, antioxidant and ROS scavenging activities (14-16). Luteolin acts as an antimetastatic agent via decrease of MMP-2 and MMP-9, iNOS and COX-2 (17,18). Luteolin enhanced the expression of Nrf2 and activates glutathione-S-transferase (GST)- $\alpha$ and GST- $\mu$ (19). Luteolin induces growth arrest by inhibiting Wnt/ $\beta$-catenin/ GSK-3 $\beta$ signaling pathway and induces apoptosis by caspase-3 in human colon cancer cells (20-23).

Thus, the objective was to determine whether luteolin induces HT-29 cell death through an antioxidant effect.

\section{Materials and methods}

Materials. Luteolin was obtained from Professor Sam Sik Kang of Seoul National University (Seoul, Republic of Korea). The xanthine, xanthine oxidase, 5,5-dimethyl-1-pyrroline-N-oxide (DMPO), propidium iodide, 3-(4,5-dimethylthiazol-2-yl)-2,5-diphenyltetrazolium bromide (MTT), 2',7'-dichlorofluorescein diacetate (DCF-DA), dihydrorhodamine (DHR) 123, N-acetylL-cysteine (NAC), reduced glutathione (GSH), buthionine sulfoximine (BSO), diethyldithiocarbamate (DEDTC), 3-amino1,2,4-triazole (ATZ), epinephrine, and L-ascorbic acid (vitamin C) were purchased from Sigma-Aldrich (St. Louis, MO, USA); 7-amino-4-chloromethylcoumarin (CMAC) was obtained from Invitrogen (Poole, Dorset, UK). 5,5',6,6'-Tetrachloro-1,1',3,3'tetraethylbenzimidazolylcarbocyanine chloride (JC-1) and Rhod2-AM were purchased from Molecular Probes (Eugene, OR, USA). Primary antibodies against manganese superoxide 
dismutase (MnSOD), catalase (CAT), cytochrome $c$, and $\beta$-actin were purchased from Santa Cruz Biotechnology (Dallas, TX, USA), and primary antibodies against Bcl-2, Bax, caspase-3, caspase-9, phospho-ERK, ERK, phospho-JNK, JNK, phosphop38, and p38 were purchased from Cell Signaling Technology (Beverly, MA, USA).

Cell culture. Human colorectal cancer (HT-29) and normal human colon (FHC) cells were obtained from the American Type Culture Collection (Rockville, MD, USA) and maintained at $37^{\circ} \mathrm{C}$ in an incubator with a humidified atmosphere of 5\% $\mathrm{CO}_{2}$. HT-29 cells were cultured in Dulbecco's modified Eagle's medium (DMEM) containing $10 \%$ heat-inactivated fetal calf serum (FCS), streptomycin $(100 \mu \mathrm{g} / \mathrm{ml})$, and penicillin $(100 \mathrm{U} / \mathrm{ml})$. Normal human colon FHC cells were cultured in a 1:1 mixture of Ham's F12 and DMEM containing HEPES (25 mM), cholera toxin $(10 \mathrm{ng} / \mathrm{ml}$, Calbiochem-Novabiochem Corp., La Jolla, CA, USA), insulin $(5 \mu \mathrm{g} / \mathrm{ml})$, transferrin $(5 \mu \mathrm{g} / \mathrm{ml})$, hydrocortisone $(100 \mathrm{ng} / \mathrm{ml})$, and $10 \%$ FCS.

Cell viability. The effect of luteolin on the viability of cells was determined using the MTT assay, which is based on the reduction of a tetrazolium salt by mitochondrial dehydrogenase in viable cells (24). Cells were treated with luteolin at various concentrations. After $48 \mathrm{~h}, 50 \mu \mathrm{l}$ MTT stock solution ( $2 \mathrm{mg} / \mathrm{ml}$ ) was added to each well to obtain a total reaction volume of $200 \mu \mathrm{l}$. After incubation for $4 \mathrm{~h}$, the plate was centrifuged at $800 \mathrm{x} \mathrm{g}$ for $5 \mathrm{~min}$ followed by aspiration of the supernatants. Formazan crystals present in each well were dissolved in $150 \mu \mathrm{l}$ DMSO and the absorbance at $540 \mathrm{~nm}$ was measured on a scanning multi-well spectrophotometer.

Detection of superoxide radical. Superoxide radical was produced by the reaction of the xanthine/xanthine oxidase system and reacted with spin trap DMPO. The DMPO-·OOH adduct was detected using electron spin resonance (ESR) spectroscopy (25). The ESR spectrum was recorded at $2.5 \mathrm{~min}$ after mixing in a phosphate buffered solution ( $\mathrm{pH} 7.4)$ with $20 \mu \mathrm{l}$ of $6 \mathrm{M}$ DMPO, $20 \mu \mathrm{l}$ xanthine oxidase $(0.25 \mathrm{U} / \mathrm{ml}), 20 \mu$ l xanthine (5 mM), and $20 \mu \mathrm{l}$ luteolin (final $50 \mu \mathrm{g} / \mathrm{ml}$ ) using the JES-FA ESR spectrometer (JEOL, Tokyo, Japan). The parameters of the ESR spectrometer were set at the following conditions: magnetic field, $336.5 \mathrm{mT}$; power, $1.00 \mathrm{~mW}$; frequency, $9.4380 \mathrm{GHz}$; modulation amplitude, $0.2 \mathrm{mT}$; gain, 500; scan time, $0.5 \mathrm{~min}$; scan width, $10 \mathrm{mT}$; time constant, $0.03 \mathrm{sec}$; and temperature, $25^{\circ} \mathrm{C}$.

Detection of hydroxyl radical. Hydroxyl radical was generated by the Fenton reaction. Hydroxyl radical reacted with DMPO and the resultant DMPO-·OH adduct was detected using an ESR spectrometer (25). The ESR spectrum was recorded $2.5 \mathrm{~min}$ after mixing in a phosphate buffered solution (pH 7.4) with $0.2 \mathrm{ml}$ of $0.3 \mathrm{M}$ DMPO, $0.2 \mathrm{ml}$ of $10 \mathrm{mM}$ $\mathrm{FeSO}_{4}, 0.2 \mathrm{ml}$ of $10 \mathrm{mM} \mathrm{H}_{2} \mathrm{O}_{2}$, and luteolin using an ESR spectrometer. The parameters of the ESR spectrometer were set at the following conditions: magnetic field, $336.5 \mathrm{mT}$; power, $1.00 \mathrm{~mW}$; frequency, $9.4380 \mathrm{GHz}$; modulation amplitude, $0.2 \mathrm{mT}$; gain, 200; scan time, $0.5 \mathrm{~min}$; scan width, $10 \mathrm{mT}$; time constant, $0.03 \mathrm{sec}$; and temperature, $25^{\circ} \mathrm{C}$.
Intracellular ROS measurement. Image analysis for the generation of intracellular ROS was achieved by seeding cells on a coverslip-loaded 6-well plate at a density of $2 \times 10^{5}$ cells/well. At $16 \mathrm{~h}$ after plating, cells were treated with luteolin at a concentration of $50 \mu \mathrm{g} / \mathrm{ml}$. After $24 \mathrm{~h}, 100 \mu \mathrm{M}$ DCF-DA was added to each well and cells were incubated for an additional $30 \mathrm{~min}$ at $37^{\circ} \mathrm{C}$. After washing with phosphate buffered saline (PBS), the stained cells were mounted onto a microscope slide in mounting medium (Dako, Carpinteria, CA, USA). Microscopic images were collected using the Laser Scanning Microscope 5 PASCAL program (Carl Zeiss, Jena, Germany) on a confocal microscope. In addition, cells were treated with luteolin at $50 \mu \mathrm{g} / \mathrm{ml}$ and incubated for an additional $48 \mathrm{~h}$ at $37^{\circ} \mathrm{C}$. After addition of $25 \mu \mathrm{M}$ DCF-DA solution, the fluorescence signal of 2', 7'-dichlorofluorescein was detected using a Perkin Elmer LS-5B spectrofluorometer (26).

Mitochondrial ROS measurement. The cells were seeded in a 96-well plate at a density of $2 \times 10^{4}$ cells/well. At $16 \mathrm{~h}$ after plating, the cells were treated with luteolin at $50 \mu \mathrm{g} / \mathrm{ml}$ and incubated for $24 \mathrm{~h}$. After addition of $20 \mu \mathrm{M}$ DHR 123 solution for $10 \mathrm{~min}$, fluorescence was detected using a Perkin Elmer LS-5B spectrofluorometer. For image analysis of the generation of mitochondrial ROS, cells were seeded on a coverslip-loaded six-well plate at a density of $2 \times 10^{5}$ cells/well. At $16 \mathrm{~h}$ after plating, cells were treated with luteolin at a concentration of $50 \mu \mathrm{g} / \mathrm{ml}$. After $24 \mathrm{~h}$, the medium was changed, $20 \mu \mathrm{M}$ DHR 123 was added to each well, and the plate was incubated for an additional $30 \mathrm{~min}$ at $37^{\circ} \mathrm{C}$. After washing with PBS, the stained cells were mounted onto a microscope slide in mounting medium. Images were acquired using the Laser Scanning Microscope 5 PASCAL program (Carl Zeiss) on a confocal microscope.

Measurement of superoxide dismutase (SOD) activity. Cells were seeded in a culture dish at a density of $1 \times 10^{5}$ cells $/ \mathrm{ml}$, and at $16 \mathrm{~h}$ after plating they were treated with luteolin at $50 \mu \mathrm{g} / \mathrm{ml}$ and incubated for additional times as indicated. The cells were then washed with cold PBS and scraped. The harvested cells were suspended in $10 \mathrm{mM}$ phosphate buffer $(\mathrm{pH} 7.5)$ and lysed on ice by sonicating twice for $15 \mathrm{sec}$. Triton X-100 (1\%) was then added to the lysates and incubated for $10 \mathrm{~min}$ on ice. The lysates were clarified by centrifugation at $5000 \mathrm{x} \mathrm{g}$ for $10 \mathrm{~min}$ at $4^{\circ} \mathrm{C}$ to remove cellular debris, and the protein content of the supernatant was determined. SOD activity was assessed by detecting the inhibition of auto-oxidation of epinephrine (27) as follows: $50 \mu \mathrm{g}$ protein was added to $50 \mathrm{mM}$ phosphate buffer (pH 10.2) containing $0.1 \mathrm{mM}$ EDTA and $0.4 \mathrm{mM}$ epinephrine. Epinephrine rapidly undergoes auto-oxidation at $\mathrm{pH} 10$ to produce adrenochrome, a pink colored product that can be measured at $480 \mathrm{~nm}$ using a UV/VIS spectrophotometer in kinetic mode. SOD inhibits the auto-oxidation of epinephrine. The rate of inhibition was monitored at $480 \mathrm{~nm}$. SOD activity was expressed as units/mg protein, and one unit of enzyme activity was defined as the amount of enzyme required for $50 \%$ inhibition of auto-oxidation of epinephrine.

Western blot analysis. Harvested cells were lysed on ice for $30 \mathrm{~min}$ in $100 \mu \mathrm{l}$ lysis buffer $[120 \mathrm{mM} \mathrm{NaCl}, 40 \mathrm{mM}$ Tris (pH 8.0), and 0.1\% NP 40] and centrifuged at 13,000 x g for 
$15 \mathrm{~min}$. Supernatants were collected from the lysates and protein concentrations were determined. Aliquots of the lysates (40 $\mu \mathrm{g}$ of protein) were boiled for $5 \mathrm{~min}$, electrophoresed on a $10 \%$ SDS-polyacrylamide gel, and transferred onto nitrocellulose membranes, which were subsequently incubated with primary antibodies. The membranes were further incubated with secondary anti-immunoglobulin-G-horseradish peroxidase conjugates (Pierce, Rockford, IL, USA). Protein bands were detected using an enhanced chemiluminescence western blotting detection kit (Amersham, Little Chalfont, Buckinghamshire, UK).

Measurement of catalase activity. Aliquots containing $50 \mu \mathrm{g}$ protein were added to $50 \mathrm{mM}$ phosphate buffer ( $\mathrm{pH} 7.0)$ containing $100 \mathrm{mM} \mathrm{H}_{2} \mathrm{O}_{2}$. The reaction mixture was incubated for $2 \mathrm{~min}$ at $37^{\circ} \mathrm{C}$ and the absorbance was monitored at $240 \mathrm{~nm}$ for $5 \mathrm{~min}$. The change in absorbance with time was proportional to the breakdown of $\mathrm{H}_{2} \mathrm{O}_{2}$ (27). Catalase activity was expressed as units/mg protein and one unit of enzyme activity was defined as the amount of enzyme required to break down $1 \mu \mathrm{M} \mathrm{H}_{2} \mathrm{O}_{2}$.

Detection of GSH level. Intracellular GSH content was measured with a commercial colorimetric assay kit (GSH-400) from Oxis International (Portland, OR, USA). After treatment with luteolin for $24 \mathrm{~h}$, cells were harvested and homogenized in a metaphosphoric working solution. After centrifugation, $50 \mu 1 \mathrm{R} 1$ solution (a solution of a chromogenic reagent in $\mathrm{HCl}$ ) was added to $900 \mu \mathrm{l}$ supernatant, followed by gentle vortex mixing. Following the addition of $50 \mu \mathrm{l}$ R2 solution $(30 \%$ $\mathrm{NaOH}$ ), the mixtures were incubated at $25 \pm 3^{\circ} \mathrm{C}$ for $10 \mathrm{~min}$. After centrifugation, the absorbance of the clear supernatant was measured at $400 \mathrm{~nm}$. The intracellular GSH level was also determined using CMAC, a GSH-sensitive fluorescence dye. Cells were incubated with $5 \mu \mathrm{M} \mathrm{CMAC}$ for $30 \mathrm{~min}$ in the dark and CMAC fluorescence images were analyzed with a Zeiss Axiovert 200 inverted microscope at an excitation wavelength of $351 \mathrm{~nm}$ and an emission wavelength of $380 \mathrm{~nm}$ (28).

Nuclear staining with Hoechst 33342. Cells were treated with luteolin at $50 \mu \mathrm{g} / \mathrm{ml}$ and the mixture was incubated for $48 \mathrm{~h}$. Hoechst 33342 (1.5 $\mu \mathrm{l}$ of a $10 \mathrm{mg} / \mathrm{ml}$ stock solution), a DNA-specific fluorescent dye, was added to each well and incubated for $10 \mathrm{~min}$ at $37^{\circ} \mathrm{C}$. The stained cells were then observed under a fluorescent microscope equipped with a CoolSNAP-Pro color digital camera to examine the degree of nuclear condensation (29).

DNA fragmentation. Cells were treated with luteolin at $50 \mu \mathrm{g} / \mathrm{ml}$ and the mixture was incubated for $48 \mathrm{~h}$. Cellular DNA fragmentation was assessed using a cytoplasmic histone-associated DNA fragmentation kit from Roche Diagnostics (Mannheim, Germany) according to the manufacturer's instructions.

Detection of sub- $G_{1}$ populations. Cells were treated with luteolin at $50 \mu \mathrm{g} / \mathrm{ml}$ and the mixture was incubated for $48 \mathrm{~h}$. Flow cytometry was performed to determine the content of apoptotic sub- $\mathrm{G}_{1}$ hypodiploid cells (30). The cells were harvested, fixed in $1 \mathrm{ml}$ of $70 \%$ ethanol for $30 \mathrm{~min}$ at $4^{\circ} \mathrm{C}$, washed twice with PBS, and then incubated in $1 \mathrm{ml}$ PBS containing $100 \mu \mathrm{g}$
A

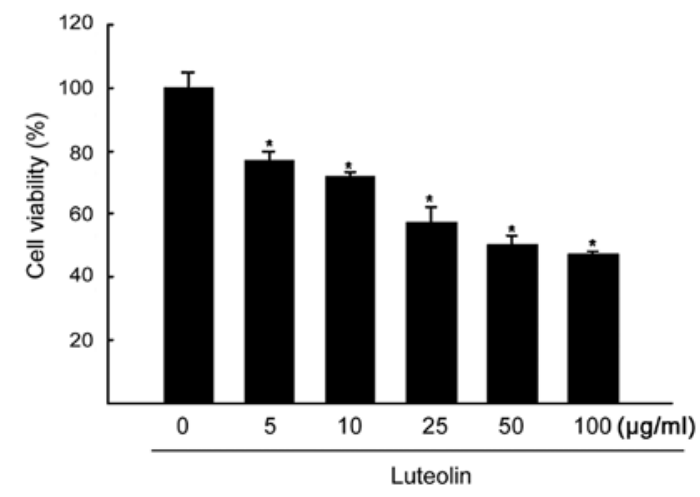

B
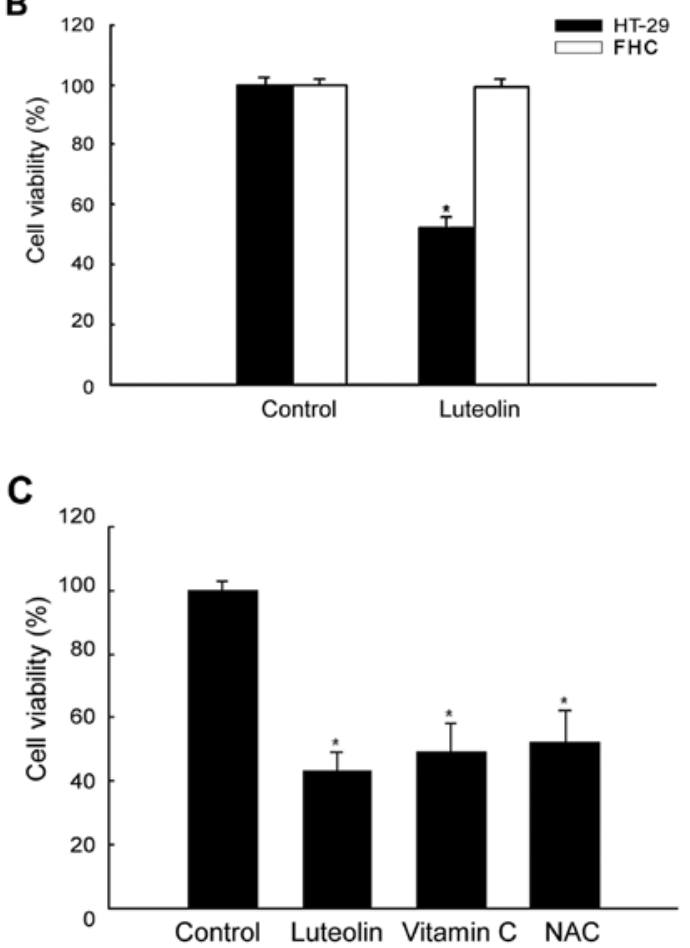

Figure 1. Cytotoxic effects of luteolin on human colon cancer cells. (A) HT-29 cells were incubated for $48 \mathrm{~h}$ in the presence of various amounts of luteolin, and cell growth rates were investigated using the MTT assay. $\mathrm{IC}_{50}$ values were defined by the concentration that inhibited growth by $50 \%$. *Significantly different from luteolin non-treated cells $(\mathrm{P}<0.05)$. (B) The cell viability of luteolin-treated $(50 \mu \mathrm{g} / \mathrm{ml}) \mathrm{HT}-29$ and FHC cells were evaluated at $48 \mathrm{~h}$ using the MTT assay. "Significantly different from control cells $(\mathrm{P}<0.05)$. (C) The cell viability of antioxidant agents in HT-29 cells were investigated using the MTT assay. *Significantly different from control cells $(\mathrm{P}<0.05)$.

propidium iodide and $100 \mu \mathrm{g}$ RNase A for $30 \mathrm{~min}$ in the dark at $37^{\circ} \mathrm{C}$. Flow cytometric analysis was performed and the proportion of sub- $\mathrm{G}_{1}$ hypodiploid cells was assessed by the histograms generated using the computer programs Cell Quest and Mod-Fit (Becton-Dickinson, Mountain View, USA).

Detection of mitochondrial membrane potential. Mitochondrial membrane potential $(\Delta \psi)$ was analyzed using JC-1, a lipophilic cationic fluorescence dye. Cells were harvested, and after changing the media, JC-1 $(10 \mu \mathrm{g} / \mathrm{ml})$ was added to each well and incubated for an additional $30 \mathrm{~min}$ at $37^{\circ} \mathrm{C}$. After washing with PBS, the stained cells were assayed using flow cytometer. 
A

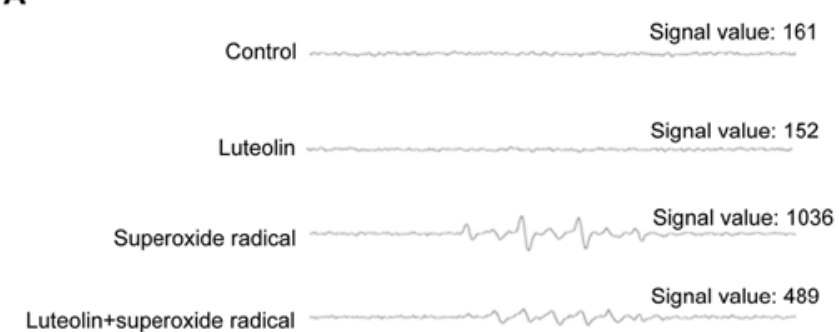

B

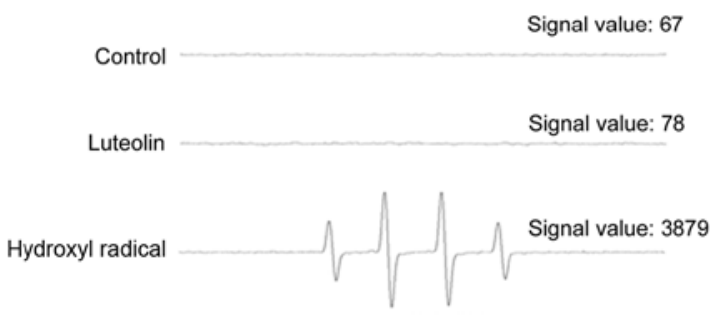

Luteolin+hydroxyl radical

C

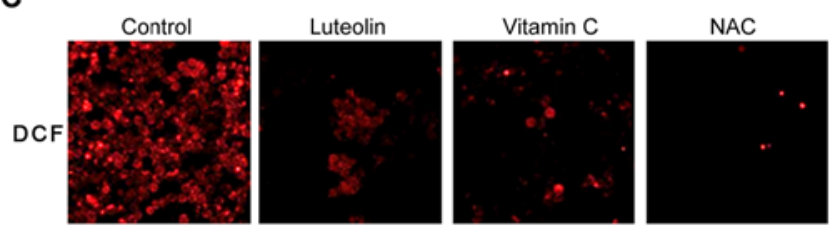

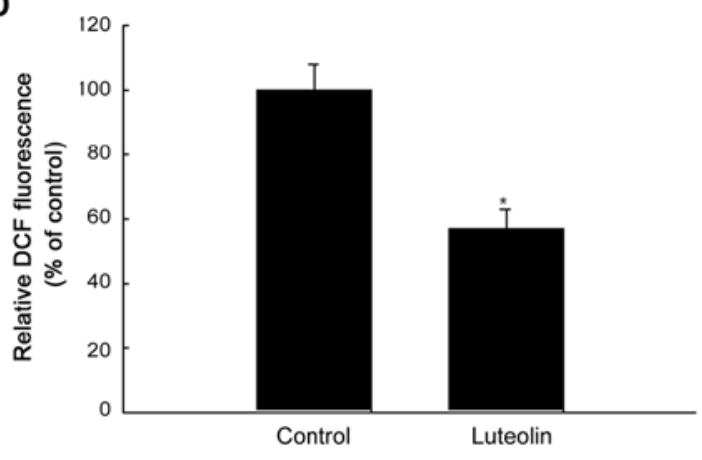

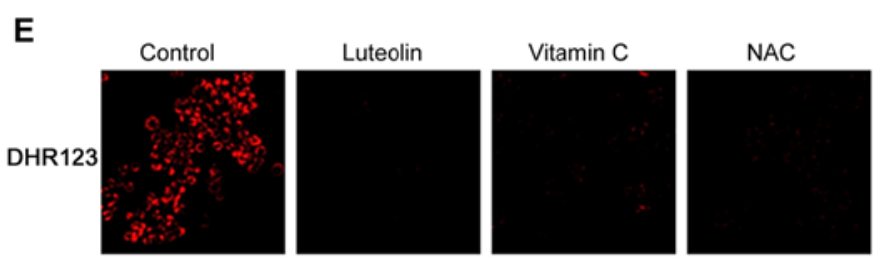

$\mathbf{F}$

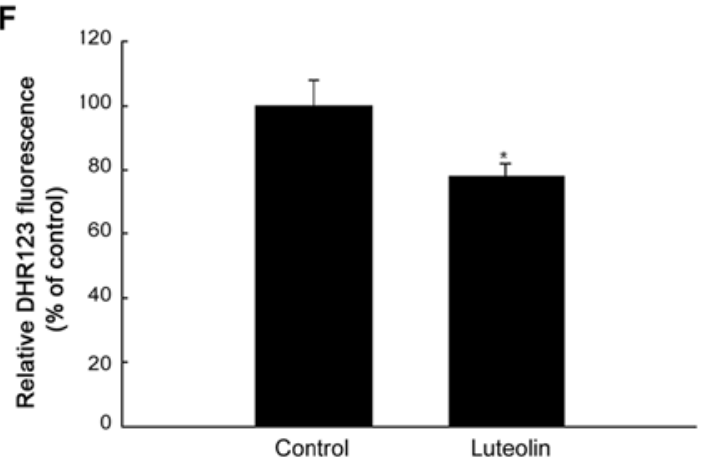

Figure 2. ROS scavenging activity of luteolin in HT-29 cells. (A) Superoxide radical was generated by xanthine/xanthine oxidase and reacted with DMPO; the resultant DMPO-·OOH adduct was detected using an ESR spectrometer. (B) Hydroxyl radical was generated by the Fenton reaction $\left(\mathrm{H}_{2} \mathrm{O}_{2} / \mathrm{FeSO}_{4}\right)$ and reacted with DMPO; the resultant DMPO- $\mathrm{OH}$ adduct was detected using an ESR spectrometer. Cells were treated with luteolin at $50 \mu \mathrm{g} / \mathrm{ml}$ and incubated for $24 \mathrm{~h}$, and intracellular ROS were detected using a (C) confocal microscope and (D) fluorescence spectrophotometer after DCF-DA staining. "Significantly different from control cells $(\mathrm{P}<0.05)$. Cells were treated with luteolin at $50 \mu \mathrm{g} / \mathrm{ml}$. After $24 \mathrm{~h}$, mitochondrial ROS were detected using $(\mathrm{E})$ confocal microscope and $(\mathrm{F})$ a fluorescence spectrophotometer after DHR 123 treatment. *Significantly different from control cells $(\mathrm{P}<0.05)$.

Determination of mitochondrial $\mathrm{Ca}^{2+}$ level. Mitochondrial $\mathrm{Ca}^{2+}$ levels were determined by Rhod2-AM (250 nM), a mitochondrial $\mathrm{Ca}^{2+}$ sensitive fluorescence dye. Cells were incubated with $250 \mathrm{nM}$ Rhod2-AM in PBS including $\mathrm{Ca}^{2+}$ for $30 \mathrm{~min}$ in the dark. Rhod2-AM fluorescence images were analyzed with a Zeiss Axiovert 200 inverted microscope at an excitation wavelength of $552 \mathrm{~nm}$ and an emission wavelength of $581 \mathrm{~nm}$ (31). In addition, cells incubated with $250 \mathrm{nM}$ Rhod2-AM in PBS including $\mathrm{Ca}^{2+}$ for 30 min in the dark were detected using a flow cytometer (Becton-Dickinson).

Transient transfection and small interfering RNA (siRNA) treatment. Overnight-seeded cells at $1.0 \times 10^{5}$ cells $/ \mathrm{ml}$ were transfected for $4 \mathrm{~h}$ with $10 \mathrm{nM}$ specific siRNAs or equal molar amounts of mismatched siRNA controls. Control siRNA (sc-37007, Santa Cruz Biotechnology). ERK-1, JNK, and p38 knockdown was performed using siRNAs against ERK-1 (sc-29308, Santa Cruz Biotechnology), JNK (5'-AAAAAGAA TGTCCTACCTTCT-3'), and p38 (5'-AGC CCA GCA ACC TAG CTG T-3'), respectively, which were transfected into cells using Lipofectamine ${ }^{\mathrm{TM}} 2000$ (Invitrogen, Carlsbad, CA, USA) following the manufacturer's instructions. At $24 \mathrm{~h}$ after transfection, the cells were treated with $50 \mu \mathrm{g} / \mathrm{ml}$ luteolin for $24 \mathrm{~h}$ and examined by immunoblotting.

Statistical analysis. All measurements were performed in triplicate and all values represent the mean \pm standard error of the mean (SEM). The results were subjected to analysis of variance (ANOVA) using Tukey's test to analyze differences. $\mathrm{P}<0.05$ was considered significant.

\section{Results}

Luteolin inhibits the growth of human colon cancer cells. The effects of luteolin on the proliferation of HT-29 cells were assessed at $48 \mathrm{~h}$ using the MTT assay, and $\mathrm{IC}_{50}(50 \%$ growth inhibitory concentration) value was determined. At 48 h, luteolin had cytotoxic effects at different concentrations. As shown in Fig. 1A, cell viability was inhibited by luteolin in a dose-dependent manner as follows: $79 \%$ at $5 \mu \mathrm{g} / \mathrm{ml}, 70 \%$ at $10 \mu \mathrm{g} / \mathrm{ml}, 60 \%$ at $25 \mu \mathrm{g} / \mathrm{ml}, 50 \%$ at $50 \mu \mathrm{g} / \mathrm{ml}$, and $42 \%$ at $100 \mu \mathrm{g} / \mathrm{ml}$. Among the tested concentrations, $50 \mu \mathrm{g} / \mathrm{ml}$ luteolin 
was selected for further investigations. The cytotoxicity of luteolin in normal colon cells (FHC) was investigated using the MTT assay. As shown in Fig. 1B, the viability of luteolintreated FHC cells was higher than that of luteolin-treated HT-29 cells. Since luteolin is an antioxidant compound, the effect of known antioxidant agents on HT-29 cell viability was determined. As shown in Fig. 1C, vitamin C and NAC, which are antioxidant agents, decreased cell viability compared with that in untreated cells.

Luteolin shows ROS scavenging activity. To determine the ROS scavenging effects of luteolin, the production of superoxide and hydroxyl radical was assessed. The superoxide radical produced via reaction of the xanthin/xanthin oxidase system and the hydroxyl radical generated via the Fenton reaction $\left(\mathrm{FeSO}_{4}+\mathrm{H}_{2} \mathrm{O}_{2}\right)$ in a cell-free system were detected by ESR spectrometry. The ESR results revealed that a specific signal was not clearly detected in the control and in the $50 \mu \mathrm{g} / \mathrm{ml}$ luteolin-treated group; however, the superoxide radical signal increased to up to 1036 in the xanthin/xanthin oxidase system, and luteolin treatment decreased the superoxide radical signal to 489 (Fig. 2A). The hydroxyl radical signal increased to up to 3879 in the $\mathrm{FeSO}_{4}+\mathrm{H}_{2} \mathrm{O}_{2}$ system, and luteolin treatment decreased the hydroxyl radical signal to 1461 (Fig. 2B). The scavenging effect of luteolin on intracellular ROS in HT-29 cells was measured. As shown in Fig. 2C, $50 \mu \mathrm{g} / \mathrm{ml}$ luteolin significantly decreased the intensity of the DCF signal compared with that in the control. Consistently, antioxidant agents significantly decreased the intensity of the DCF signal. The red fluorescence intensity of ROS measured using a confocal microscope was decreased in luteolin-treated cells at $50 \mu \mathrm{g} / \mathrm{ml}$. In addition, ROS levels detected with a spectrofluorometer were significantly lower in luteolin-treated than in untreated cells (Fig. 2D). To examine the scavenging effect of luteolin on mitochondrial ROS in HT-29 cells, the DHR 123 fluorescence dye was used to detect mitochondrial ROS in cells treated with or without luteolin. Confocal microscopy revealed that luteolin reduced the red fluorescence intensity of mitochondrial ROS in untreated cells (Fig. 2E). Fluorescence spectrometric data revealed that luteolin treatment decreased the level of mitochondrial ROS compared with that in untreated cells (Fig. 2F).

Effects of luteolin on antioxidant enzymes in HT-29 cells. Assessment of the effect of luteolin on the activity of antioxidant enzymes showed that luteolin increased SOD and CAT activity in a time-dependent manner until $24 \mathrm{~h}$ (Fig. 3A). The protein levels of MnSOD and CAT increased in response to treatment with $50 \mu \mathrm{g} / \mathrm{ml}$ luteolin for $24 \mathrm{~h}$ (Fig. 3B). To determine whether MnSOD activity was related to luteolin-induced cytotoxicity, cells were treated with the MnSOD inhibitor DEDTC and subjected to the MTT assay. As shown in Fig. 3C, DEDTC treatment attenuated the cytotoxic effect of luteolin. To examine the effect of CAT on luteolin-induced cytotoxicity, cells were pretreated with the CAT inhibitor ATZ (32). As shown in Fig. 3D, ATZ treatment attenuated the cytotoxic effect of luteolin.

Effect of luteolin on glutathione. GSH is one of the most abundant intracellular antioxidants, and determination of changes in the level of GSH provides a method to monitor oxidative
A

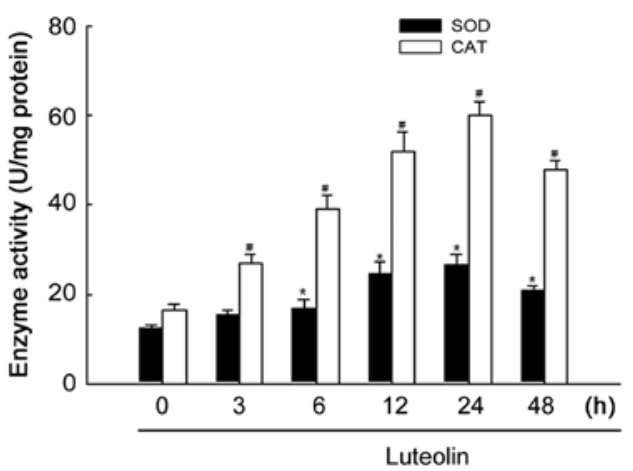

B

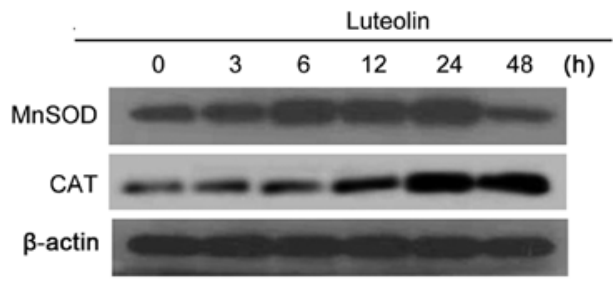

C

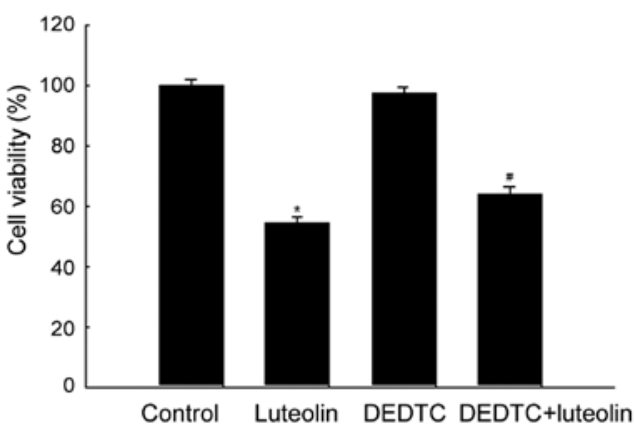

D

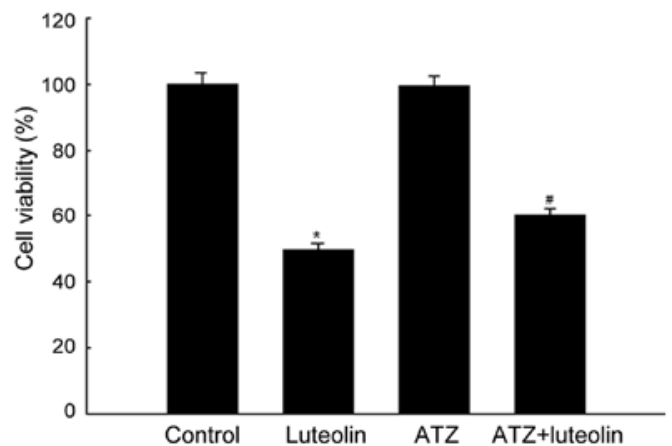

Figure 3. Effects of luteolin on antioxidant enzymes. Cells were treated with luteolin at $50 \mu \mathrm{g} / \mathrm{ml}$ for $24 \mathrm{~h}$. (A) SOD and CAT activities are expressed as average enzyme units per $\mathrm{mg}$ protein \pm SEM. ${ }^{*}$ " Significantly different from non-treated cells $(\mathrm{P}<0.05)$. (B) Western blot analysis was performed using anti-MnSOD and anti-CAT antibodies. (C) The viability of HT-29 cells after pretreatment with the MnSOD inhibitor DEDTC and treatment with luteolin was determined by the MTT assay. *Significantly different from control cells

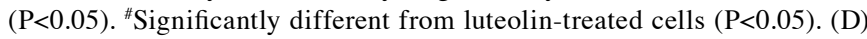
The viability of HT-29 cells after pretreatment with the CAT inhibitor ATZ (3-amino-1, 2, 4 triazole) and treatment with luteolin was determined by the MTT assay. "Significantly different from control cells $(\mathrm{P}<0.05)$; " significantly different from luteolin-treated cells $(\mathrm{P}<0.05)$.

stress within cells. The GSH-sensitive fluorescent dye, CMAC, can be used as a probe to evaluate the level of intracellular GSH (28). As shown in Fig. 4A, cells treated with luteolin at 
A

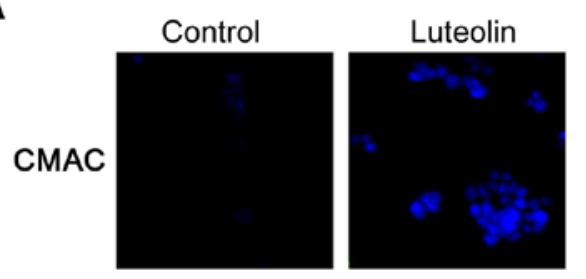

B

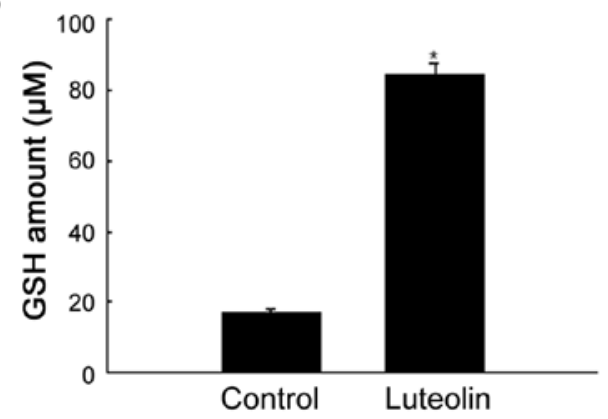

C

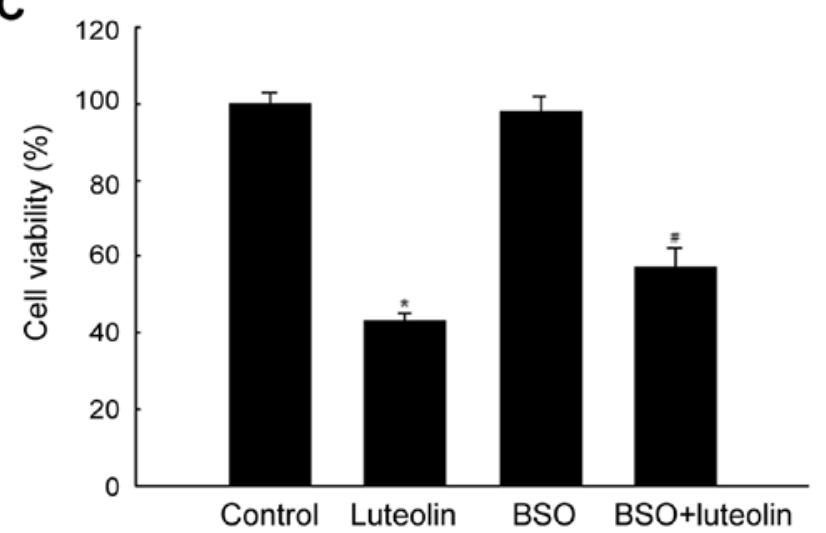

Figure 4. Effect of luteolin on cellular GSH amount. Cells were treated with luteolin at $50 \mu \mathrm{g} / \mathrm{ml}$ for $24 \mathrm{~h}$ and cellular GSH levels were detected using (A) confocal microscope after CMAC staining and (B) a colorimetric assay kit *Significantly different from control cells $(\mathrm{P}<0.05)$. (C) The viability of HT-29 cells after pretreatment with the glutathione synthesis inhibitor BSO and treatment with luteolin was determined by the MTT assay. *Significantly different from control cells $(\mathrm{P}<0.05)$; ${ }^{\text {}}$ significantly different from luteolin-treated cells $(\mathrm{P}<0.05)$.

$50 \mu \mathrm{g} / \mathrm{ml}$ and stained with CMAC showed higher blue fluorescence intensity of cellular GSH measured using a confocal microscope than untreated cells. This pattern was confirmed by measurement of the cellular GSH level. Cellular GSH level was significantly higher in luteolin-treated than in control cells (Fig. 4B). To determine whether GSH was related to luteolininduced cytotoxicity, cells were treated with the glutathione synthesis inhibitor BSO and subjected to the MTT assay. As shown in Fig. 4C, BSO treatment attenuated the cytotoxic effect of luteolin.

Luteolin induces apoptosis by the mitochondrial pathway. To study the cytotoxic effect of luteolin via apoptotic cell death, cell nuclei were stained with Hoechst 33342 and assessed by microscopy. The microscopic images in Fig. 5A show that control cells had intact nuclei, whereas luteolin-treated cells had significant nuclear fragmentation, which is characteristic of apoptosis. In addition, the levels of DNA fragmentation were higher in the luteolin-treated group than in the control group (Fig. 5B). In addition to the morphological evaluation, the effect of luteolin on apoptosis in HT-29 cells was confirmed by apoptotic sub- $\mathrm{G}_{1}$ DNA analysis. As shown in Fig. 5C, luteolin-treated cells were $25 \%$ in the apoptotic sub-G $G_{1}$ DNA content compared with $4 \%$ of the apoptotic sub- $\mathrm{G}_{1}$ DNA content in control group. During the apoptotic process, the mitochondrial membrane pore opening induces the loss of mitochondrial $\Delta \psi$, which induces the release of cytochrome $c$ from mitochondria. Luteolin treatment resulted in the loss of $\Delta \psi$, as measured with the JC-1 dye (Fig. 5D). The effect of luteolin on apoptosis-related protein expression was determined by western blot analysis of the antiapoptotic and proapoptotic proteins Bcl-2 and Bax. As shown in Fig. 5E, luteolin upregulated Bax but downregulated Bcl-2 expression. The loss of $\Delta \psi$ induces the release of cytochrome $c$ from mitochondria. As shown in Fig. 5E, luteolin induced the release of cytochrome $c$ from mitochondria to the cytosol. The level of active (cleaved) caspase- 9 was examined by western blotting because this enzyme is activated in response to mitochondrial membrane disruption (33). As shown in Fig. 5E, luteolin upregulated the active form of caspase- 9 and caspase- 3 . Excessive $\mathrm{Ca}^{2+}$ within mitochondria can induce apoptosis by opening the mitochondrial permeability transition pore (34); therefore, we investigated whether mitochondrial $\mathrm{Ca}^{2+}$ changes occurred in response to luteolin. Our data demonstrated that luteolin at $50 \mu \mathrm{g} / \mathrm{ml}$ caused a sustained elevation of mitochondrial $\mathrm{Ca}^{2+}$ compared with that in the control. These data were determined by confocal (Fig. 5F) imaging and FACS (Fig. 5G) analysis using Rhod2-AM.

Effect of luteolin on the MAPK signaling pathway. The MAPK signaling pathway is activated in response to certain cellular stress conditions, and it is implicated in cellular death or survival signaling $(35,36)$. To investigate whether the MAPK pathway is involved in luteolin-induced apoptosis, the activity of MAPK was assessed in luteolin-treated cells. Control cells showed low or undetectable levels of phosphorylated MAPK, whereas luteolin at $50 \mu \mathrm{g} / \mathrm{ml}$ increased the phosphorylation of all three MAPK in a time-dependent manner (Fig. 6A). Next, the effects of the specific ERK, JNK, and p38 MAP kinase inhibitors U0126, SP600125, and SB203580 on luteolin-induced apoptosis were examined by the MTT assay. As shown in Fig. 6B, luteolin significantly reduced the cell viability, whereas pretreatment with SP600125 and SB203580 except U0126 attenuated the cytotoxic effect of luteolin. Similar results were obtained in response to transfection with MAPK-specific siRNAs (Fig. 6C).

\section{Discussion}

Cancer cells need an increased energy supply to support high rates of metabolism. Normally, ATP is produced with high efficiency through oxidative phosphorylation in mitochondria. An alternative metabolic pathway is adopted (enhanced glycolysis) when mitochondrial ATP production is compromised. The enhanced oxidative stress observed in cancer cells can result not only from ROS overproduction but also from low levels or inactivation of antioxidant mechanisms (37). 
A

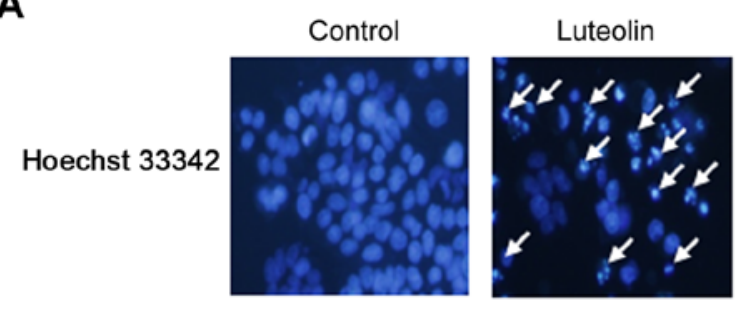

B

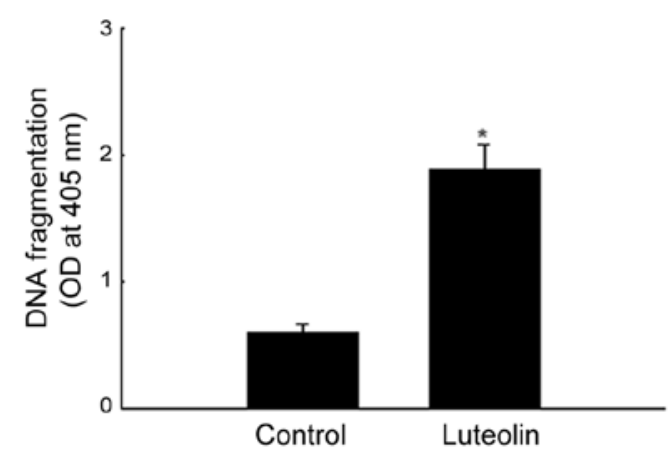

C

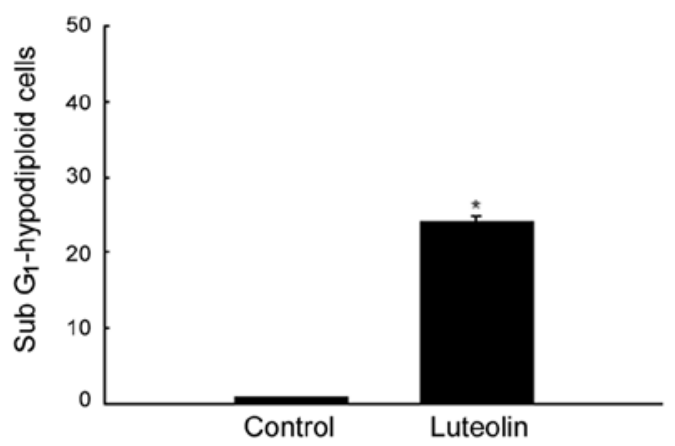

D

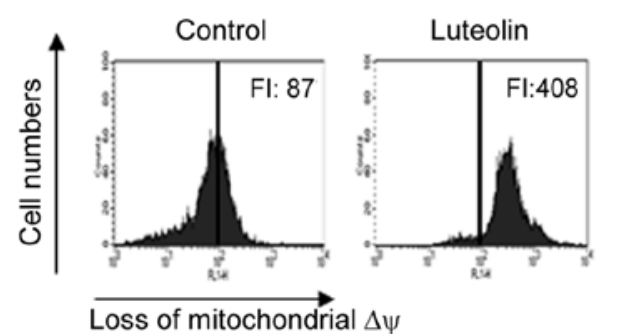

E

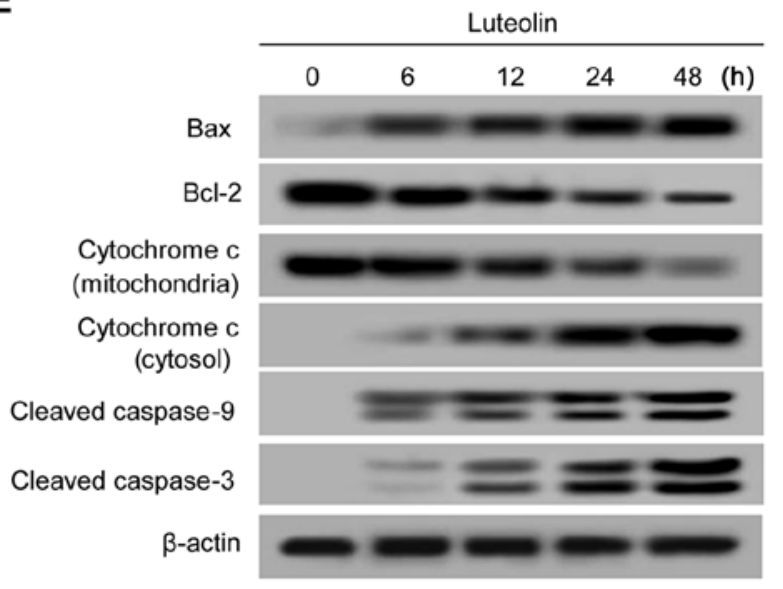

$\mathbf{F}$
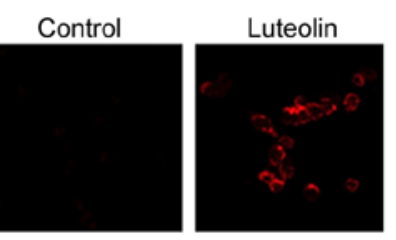

G
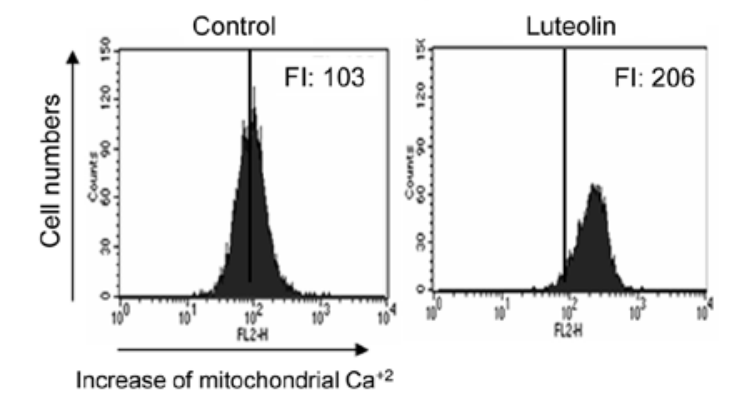

Increase of mitochondrial $\mathrm{Ca}^{+2}$

Rhod-2AM

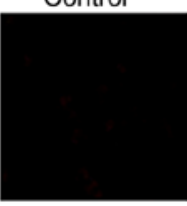

Figure 5. Effect of luteolin on mitochondria-mediated apoptosis. (A) Apoptotic body formation was observed under a fluorescence microscope after Hoechst 33342 staining and arrows indicate apoptotic bodies. (B) The apoptotic effect of luteolin was measured by the ELISA kit-based quantification of cytoplasmic histone-associated DNA fragmentation. "Significantly different from control cells $(P<0.05)$. (C) The apoptotic sub- $G_{1}$ DNA content was detected by flow cytometry after propidium iodide staining. "Significantly different from control cells $(\mathrm{P}<0.05)$. (D) The $\Delta \psi \mathrm{m}$ was analyzed by flow cytometry after staining cells with JC-1. (E) Cell lysates were electrophoresed and Bax, Bcl-2, cytochrome $c$, active caspase-9, and active caspase-3 proteins were detected by their specific antibodies. Cells were treated with luteolin at $50 \mu \mathrm{g} / \mathrm{ml}$ for $48 \mathrm{~h}$ and mitochondrial $\left[\mathrm{Ca}^{2+}\right]$ level was detected using (F) a confocal microscope and (G) flow cytometry after Rhod2-AM treatment.

The enhanced constitutive oxidative stress renders tumor cells highly dependent on endogenous antioxidants to protect them from continuous intracellular ROS injury (38).

Luteolin has anticancer activity mediated by its role as a DNA topoisomerase II poison, its inhibition of invasive activity, and the induction of cell cycle arrest and apoptosis (39-41).

The present data indicated that luteolin induced apoptosis in HT-29 cells by a caspase-dependent pathway with mito- chondrial involvement. In the present study, we used a direct approach to examine the scavenging activity of luteolin with hydroxyl and superoxide radical, and the results suggested that luteolin has strong antioxidant activity. To examine the role of ROS in luteolin-induced apoptosis, ROS production was examined using an intracellular oxidant-sensitive fluorescent probe, DCF-DA, and a mitochondrial oxidant-sensitive fluorescent probe, DHR123. The results showed that treatment with luteolin had ROS scavenging effect compared with that in the control, 
A

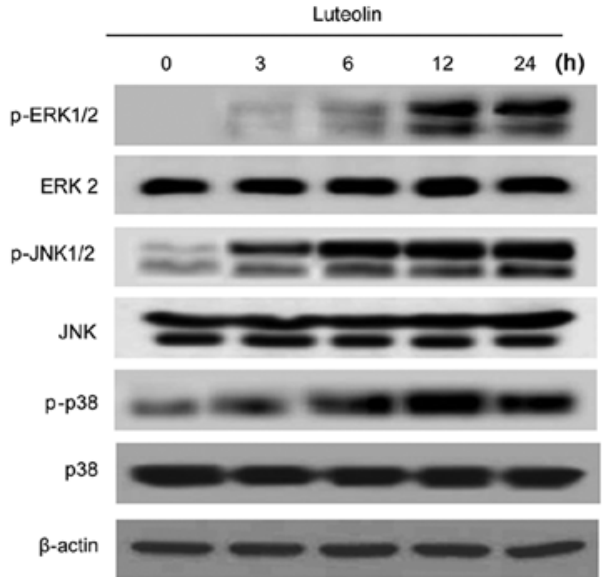

B

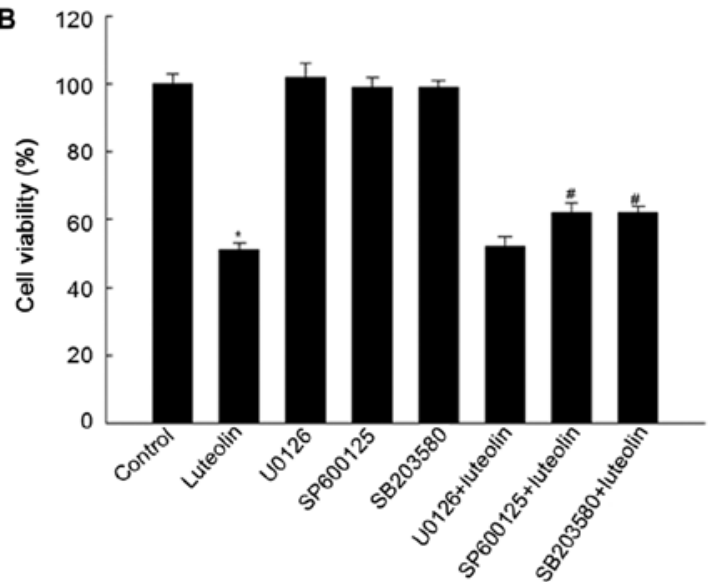

C

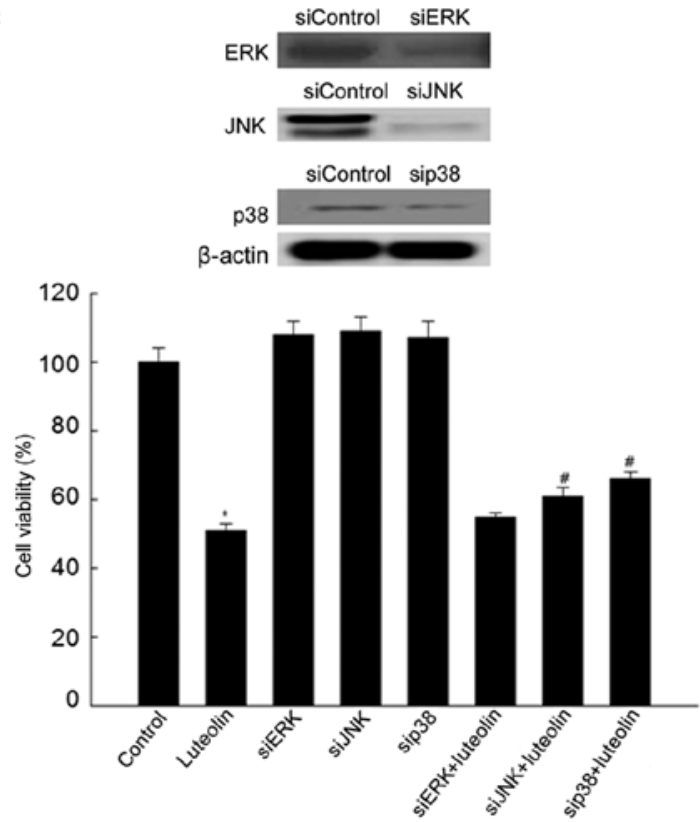

Figure 6. Effect of luteolin on the MAPK signaling pathway. Cells were treated with luteolin at $50 \mu \mathrm{g} / \mathrm{ml}$ for $24 \mathrm{~h}$ to detect the expression of MAPK signaling proteins. (A) Cell lysates were electrophoresed and immunoblotted using antiERK2, anti-phospho-ERK1/2, anti-JNK, anti-phospho-JNK, anti-p38, and anti-phospho-p38 antibodies. (B) The cell viability after pretreatment with the ERK, JNK, and p38 MAPK inhibitors U0126, SP600125, and SB203580 and treatment with luteolin was determined by the MTT assay. *Significantly different from control cells $(\mathrm{P}<0.05)$; " significantly different from luteolin-treated cells $(\mathrm{P}<0.05)$. (C) The viability of HT-29 cells after transfection with siRNAs against ERK, JNK, and p38 and treatment with luteolin was determined by the MTT assay. *Significantly different from control cells $(\mathrm{P}<0.05)$; ${ }^{*}$ significantly different from luteolin-treated cells $(\mathrm{P}<0.05)$. indicating that antioxidant effect of luteolin induced cell death in HT-29 cells.

Polyphenolic antioxidants are scavengers of free radicals and modifiers of various enzymatic functions. Luteolin is a flavonoid that contains two phenolic structures. To determine whether luteolin-induced HT-29 cell apoptosis was associated with the antioxidant properties of luteolin, we examined the antioxidant activity of luteolin. Decreased activity and expression of mitochondrial MnSOD was reported in certain colorectal carcinomas, probably accounting for increased superoxide radical production (42). Accumulation of superoxide radical stimulates cell growth by altering the redox status of transcriptional factors and cell cycle regulatory proteins (43). Moreover, induced overexpression of MnSOD suppresses malignant phenotypes in experimental in vitro model. Therefore, MnSOD is considered to be a tumor suppressor that acts indirectly via ROS. In the present study, we examined the expression of the MnSOD and CAT proteins during luteolininduced apoptosis. Our results showed that the MnSOD and CAT inhibitors DEDTC and ATZ attenuated luteolin-induced apoptosis. MnSOD and CAT act as tumor suppressor genes in several human cancer cells (44). The mechanism by which MnSOD suppresses cancer development remains unknown. However, the expression of this antioxidant enzyme may play a significant role in maintaining cellular redox status. The tumor suppressor effects of MnSOD overexpression are mediated in part by the modulation of specific oncogenes. The relationship between MnSOD expression, the modulation of DNA-binding activity, and the transcriptional activation of redox-sensitive oncoproteins and tumor suppressor proteins was reported recently (45-48). The present data indicated that luteolin increased GSH levels in HT-29 cells. This was confirmed by experiments using the glutathione synthesis inhibitor BSO, which indicated that GSH was related to luteolin-induced apoptosis. In addition, the present study demonstrated that JNK and p38 MAPK pathway was involved in apoptosis induced by luteolin. Taken together, the results of the present study suggest that luteolin-induced apoptosis is associated with the antioxidant properties of luteolin.

\section{Acknowledgements}

This work was supported by grant from the Basic Science Research Program (NRF-2016R1A6A3A11932235) through the National Research Foundation of Korea (NRF) funded by the Ministry of Education, Science and Technology, and by grant from the Basic Research Laboratory Program (NRF-2017R1A4A1014512) by NRF grant funded by the Korea government (MSIP).

\section{References}

1. Ferlay J, Soerjomataram I, Dikshit R, Eser S, Mathers C, Rebelo M, Parkin DM, Forman D and Bray F: Cancer incidence and mortality worldwide: Sources, methods and major patterns in GLOBOCAN 2012. Int J Cancer 136: E359-E386, 2015.

2. Lee HH, Kim SK, Choi HH, Kim HK, Kim SS, Chae HS, Cho H and Cho YS: Post-colonoscopy colorectal cancers in averagerisk Korean subjects with a normal initial colonoscopy. Turk J Gastroenterol 27: 17-22, 2016.

3. Vargas AJ and Thompson PA: Diet and nutrient factors in colorectal cancer risk. Nutr Clin Pract 27: 613-623, 2012. 
4. Yang SY, Kim YS, Lee JE, Seol J, Song JH, Chung GE, Yim JY, Lim SH and Kim JS: Dietary protein and fat intake in relation to risk of colorectal adenoma in Korean. Medicine (Baltimore) 95: e5453, 2016.

5. Mehta RS, Nishihara R, Cao Y, Song M, Mima K, Qian ZR, Nowak JA, Kosumi K, Hamada T, Masugi Y, et al: Association of dietary patterns with risk of colorectal cancer subtypes classified by fusobacterium nucleatum in tumor tissue. JAMA Oncol 6374 2016, 2017.

6. Nogueira V and Hay N: Molecular pathways: Reactive oxygen species homeostasis in cancer cells and implications for cancer therapy. Clin Cancer Res 19: 4309-4314, 2013.

7. Harris IS, Treloar AE, Inoue S, Sasaki M, Gorrini C, Lee KC, Yung KY, Brenner D, Knobbe-Thomsen CB, Cox MA, et al: Glutathione and thioredoxin antioxidant pathways synergize to drive cancer initiation and progression. Cancer Cell 27: 211-222, 2015.

8. Schumacker PT: Reactive oxygen species in cancer: A dance with the devil. Cancer Cell 27: 156-157, 2015.

9. Ho BY, Wu YM, Chang KJ and Pan TM: Dimerumic acid inhibits SW620 cell invasion by attenuating $\mathrm{H}_{2} \mathrm{O}_{2}$-mediated MMP-7 expression via JNK/C-Jun and ERK/C-Fos activation in an AP-1-dependent manner. Int J Biol Sci 7: 869-880, 2011.

10. Impei S, Gismondi A, Canuti L and Canini A: Metabolic and biological profile of autochthonous Vitis vinifera L. ecotypes. Food Funct 6: 1526-1538, 2015.

11. Potze L, di Franco S, Kessler JH, Stassi G and Medema JP: Betulinic acid kills colon cancer stem cells. Curr Stem Cell Res Ther 11: 427-433, 2016.

12. Pandurangan AK and Esa NM: Luteolin, a bioflavonoid inhibits colorectal cancer through modulation of multiple signaling pathways: A review. Asian Pac J Cancer Prev 15: 5501-5508, 2014

13. Gismondi A, Di Marco G, Canuti L and Canini A: Antiradical activity of phenolic metabolites extracted from grapes of white and red Vitis vinifera L. cultivars. Vitis 56: 19-26, 2017

14. Kumar S and Pandey AK: Chemistry and biological activities of flavonoids: An overview. Scientific World Journal 2013: 162750 2013.

15. Zhang YC, Gan FF, Shelar SB, Ng KY and Chew EH: Antioxidant and Nrf2 inducing activities of luteolin, a flavonoid constituent in Ixeris sonchifolia Hance, provide neuroprotective effects against ischemia-induced cellular injury. Food Chem Toxicol 59: 272-280, 2013

16. Kasala ER, Bodduluru LN, Barua CC and Gogoi R: Antioxidant and antitumor efficacy of Luteolin, a dietary flavone on benzo(a) pyrene-induced experimental lung carcinogenesis. Biomed Pharmacother 82: 568-577, 2016.

17. Pandurangan AK, Dharmalingam $P$, Sadagopan SK and Ganapasam S: Luteolin inhibits matrix metalloproteinase 9 and 2 in azoxymethane-induced colon carcinogenesis. Hum Exp Toxicol 33: 1176-1185, 2014.

18. Pandurangan AK, Ananda Sadagopan SK, Dharmalingam P and Ganapasam S: Inhibitory effect of luteolin on azoxymethane induced colon carcinogenesis: Involvement of iNOS and COX-2. Pharmacogn Mag 10: 306-310, 2014.

19. Pandurangan AK, Ananda Sadagopan SK, Dharmalingam $P$ and Ganapasam S: Luteolin, a bioflavonoid inhibits Azoxymethaneinduced colorectal cancer through activation of Nrf2 signaling. Toxicol Mech Methods 24: 13-20, 2014.

20. Pandurangan AK, Dharmalingam P, Sadagopan SK, Ramar M, Munusamy A and Ganapasam S: Luteolin induces growth arrest in colon cancer cells through involvement of Wnt/ $\beta$-catenin/GSK-3 $\beta$ signaling. J Environ Pathol Toxicol Oncol 32: 131-139, 2013.

21. Ashokkumar P and Sudhandiran G: Luteolin inhibits cell proliferation during Azoxymethane-induced experimental colon carcinogenesis via Wnt/ $\beta$-catenin pathway. Invest New Drugs 29: 273-284, 2011

22. Attoub S, Hassan AH, Vanhoecke B, Iratni R, Takahashi T, Gaben AM, Bracke M, Awad S, John A, Kamalboor HA, et al: Inhibition of cell survival, invasion, tumor growth and histone deacetylase activity by the dietary flavonoid luteolin in human epithelioid cancer cells. Eur J Pharmacol 651: 18-25, 2011.

23. Pandurangan AK and Ganapasam S: Cytotoxic effect of luteolin on human colorectal cancer cell line (HCT-15): Crucial involvement of reactive oxygen species. Middle East J Cancer 4: 177-182, 2013.

24. Safi W, Kuehnl A, Nüssler A, Eckstein HH and Pelisek J: Differentiation of human $\mathrm{CD} 14^{+}$monocytes: An experimental investigation of the optimal culture medium and evidence of a lack of differentiation along the endothelial line. Exp Mol Med 48: e227, 2016.
25. Kimura S, Inoguchi T, Yamasaki T, Yamato M, Ide M, Sonoda N, Yamada K and Takayanagi R: A novel DPP-4 inhibitor teneligliptin scavenges hydroxyl radicals: In vitro study evaluated by electron spin resonance spectroscopy and in vivo study using DPP-4 deficient rats. Metabolism 65: 138-145, 2016.

26. Kim HB and Yoo BS: Propolis inhibits UVA-induced apoptosis of human keratinocyte $\mathrm{HaCaT}$ cells by scavenging ROS. Toxicol Res 32: 345-351, 2016

27. Carrillo MC, Kanai S, Nokubo M and Kitani K: (-) deprenyl induces activities of both superoxide dismutase and catalase but not of glutathione peroxidase in the striatum of young male rats. Life Sci 48: 517-521, 1991.

28. Tauskela JS, Hewitt K, Kang LP, Comas T, Gendron T, Hakim A, Hogan M, Durkin J and Morley P: Evaluation of glutathionesensitive fluorescent dyes in cortical culture. Glia 30: 329-341, 2000.

29. Fernando PM, Piao MJ, Kang KA, Ryu YS, Hewage SR, Chae SW and Hyun JW: Rosmarinic acid attenuates cell damage against UVB radiation-induced oxidative stress via enhancing antioxidant effects in human HaCaT cells. Biomol Ther (Seoul) 24: 75-84, 2016.

30. Nicoletti I, Migliorati G, Pagliacci MC, Grignani F and Riccardi C: A rapid and simple method for measuring thymocyte apoptosis by propidium iodide staining and flow cytometry. J Immunol Methods 139: 271-279, 1991.

31. Zhang D and Armstrong JS: Bax and the mitochondrial permeability transition cooperate in the release of cytochrome c during endoplasmic reticulum-stress-induced apoptosis. Cell Death Differ 14: 703-715, 2007.

32. Gold-Smith F, Fernandez A and Bishop K: Mangiferin and cancer: Mechanisms of action. Nutrients 8: 396, 2016.

33. Tait SW and Green DR: Mitochondrial regulation of cell death. Cold Spring Harb Perspect Biol 5: 008706, 2013.

34. Cao XH, Zhao SS, Liu DY, Wang Z, Niu LL, Hou LH and Wang CL: ROS-Ca(2+) is associated with mitochondria permeability transition pore involved in surfactin-induced MCF-7 cells apoptosis. Chem Biol Interact 190: 16-27, 2011.

35. Cheng YY, Yang JS, Tsai SC, Liaw CC, Chung JG, Huang LJ, Lee KH,Lu CC, Chien HC, Tsuzuki M, et al: The newly synthesized 2-(3-hydroxy-5-methoxyphenyl)-6,7-methylenedioxyquinolin4-one triggers cell apoptosis through induction of oxidative stress and upregulation of the p38 MAPK signaling pathway in HL-60 human leukemia cells. Oncol Rep 28: 1482-1490, 2012.

36. Hsieh CJ, Kuo PL, Hsu YC, Huang YF, Tsai EM and Hsu YL: Arctigenin, a dietary phytoestrogen, induces apoptosis of estrogen receptor-negative breast cancer cells through the ROS/p38 MAPK pathway and epigenetic regulation. Free Radic Biol Med 67: 159-170, 2014.

37. Schulze A and Harris AL: How cancer metabolism is tuned for proliferation and vulnerable to disruption. Nature 491: 364-373, 2012.

38. Huang P, Feng L, Oldham EA, Keating MJ and Plunkett W: Superoxide dismutase as a target for the selective killing of cancer cells. Nature 407: 390-395, 2000

39. Lee LT, Huang YT, Hwang JJ, Lee AY, Ke FC, Huang CJ, Kandaswami C, Lee PP and Lee MT: Transinactivation of the epidermal growth factor receptor tyrosine kinase and focal adhesion kinase phosphorylation by dietary flavonoids: Effect on invasive potential of human carcinoma cells. Biochem Pharmacol 67: 2103-2114, 2004.

40. Sonoda M, Nishiyama T, Matsukawa Y and Moriyasu M: Cytotoxic activities of flavonoids from two Scutellaria plants in Chinese medicine. J Ethnopharmacol 91: 65-68, 2004.

41. Lim DY, Jeong Y, Tyner AL and Park JH: Induction of cell cycle arrest and apoptosis in HT-29 human colon cancer cells by the dietary compound luteolin. Am J Physiol Gastrointest Liver Physiol 292: G66-G75, 2007.

42. Miar A, Hevia D, Muñoz-Cimadevilla H, Astudillo A, Velasco J, Sainz RM and Mayo JC: Manganese superoxide dismutase (SOD2/MnSOD)/catalase and SOD2/GPx1 ratios as biomarkers for tumor progression and metastasis in prostate, colon, and lung cancer. Free Radic Biol Med 85: 45-55, 2015.

43. Sarsour EH, Kalen AL and Goswami PC: Manganese superoxide dismutase regulates a redox cycle within the cell cycle. Antioxid Redox Signal 20: 1618-1627, 2014.

44. Hart PC, Mao M, de Abreu AL, Ansenberger-Fricano K, Ekoue DN, Ganini D, Kajdacsy-Balla A, Diamond AM, Minshall RD, Consolaro ME, et al: MnSOD upregulation sustains the Warburg effect via mitochondrial ROS and AMPKdependent signalling in cancer. Nat Commun 6: 6053, 2015. 
45. Dhar SK, Tangpong J, Chaiswing L, Oberley TD and St Clair DK Manganese superoxide dismutase is a p53-regulated gene that switches cancers between early and advanced stages. Cancer Res 71: 6684-6695, 2011.

46. Sun Y, St Clair DK, Xu Y, Crooks PA and St Clair WH: A NADPH oxidase-dependent redox signaling pathway mediates the selective radiosensitization effect of parthenolide in prostate cancer cells. Cancer Res 70: 2880-2890, 2010.
47. Becuwe P, Ennen M, Klotz R, Barbieux C and Grandemange S: Manganese superoxide dismutase in breast cancer: From molecular mechanisms of gene regulation to biological and clinical significance. Free Radic Biol Med 77: 139-151, 2014.

48. Dhar SK and St Clair DK: Manganese superoxide dismutase regulation and cancer. Free Radic Biol Med 52: 2209-2222, 2012. 